\title{
Uji Organoleptik Serbuk Biji Azadirachta Indica Dalam Variasi Minyak
}

\author{
Organoleptic Powder Of Azadirachta Indica Seeds In Oil Variations
}

\author{
Udrika Lailatul Qodri \\ Program Studi Farmasi, Fakultas Ilmu Kesehatan, Universitas Ibrahimy \\ Email: udrika.lailatulq@gmail.com
}

\begin{abstract}
ABSTRAK
Tanaman nimba (Azadirachta indica) banyak ditemukan di Kabupaten Situbondo, dan pada saat ini kurang dimanfaatkan Tanaman nimba memiliki banyak manfaat, baik dalam bidang pertanian yaitu sebagai pestisida maupun dalam bidang farmasi yaitu sebagai obat-obatan. Kandungan senyawa aktif insektisida lebih banyak ditemukan dalam biji nimba. Senyawa aktif terbesar yang bersifat insektisida dalam biji nimba (Azadirachta indica) yaitu azadirachtin. Azadirachtin merupakan golongan senyawa terpenoid yang umumya bersifat non polar sehingga proses ekstraksinya dapat menggunkaan pelarut non polar. Pada penelitian ini menggunakan minyak sebagai pelarut pembawa, telah diketahui bahwa minyak bersifat non polar. Penelitian ini dilakukan dengan tujuan untuk mengatahui hasil uji organoleptik serbuk biji nimba (Azadirachta indica) dalam variasi minyak. Hasil uji organoleptik menunjukkan perubahan fisik dari ketiga minyak, terlihat jelas pada warna yang dihasilkan setelah perlakuan. Hasil dari ketiga sampel menunjukkan warna tidak jernih (keruh). Aroma yang dihasilkan dari masing-masing minyak yaitu tidak tengik serta pada pengukuran $\mathrm{pH}$ menunjukkan kenaikan dari 5 menjadi 6.
\end{abstract}

Kata Kunci: Biji Azadirachta Indica, Minyak, Uji Organoleptik

\begin{abstract}
Neem plants (Azadirachta indica) are commonly found in Situbondo Regency, and currently underutilized nimba plants have many benefits, both in agriculture as pesticides and in pharmaceuticals as medicines. The content of the active compound is more commonly found in nimba seeds. The largest active compound that is an insecticide in neem seeds (Azadirachta indica) is azadirachtin. Azadirachtin is a group of terpenoid compounds which are generally non-polar so that the extraction process can use non-polar solvents. In this study using oil as a carrier solvent, it is known that oil is non-polar. This research was conducted with the aim to know the organoleptic test results of neem seed powder (Azadirachta indica) in oil variations. Organoleptic test results showed physical changes of the three oils, clearly visible in the color produced after treatment. The results of the three samples showed that the color was not clear (turbid). The aroma produced from each oil is not rancid and the $\mathrm{pH}$ measurement shows an increase from 5 to 6.
\end{abstract}

Keywords: Azadirachta Indica Seed, Oil, Organoleptic Test 


\section{PENDAHULUAN}

Nimba (Azadirachta indica) adalah tanaman yang memiliki senyawa metabolit sekunder dan dapat digunakan sebagai insektisida nabati. Tanamaan nimba sendiri saat ini jarang dimanfaatkan kelebihannya, Tanaman ini banyak ditemukan di Kabupaten Situbondo. Menurut Schmutterer (1990) kandungan bahan aktif insektisida biji mimba lebih banyak dibandingkan daun. Senyawa aktif terbesar yang bersifat insektisida pada tanaman nimba (Azadirachta indica) adalah azadirachtin, senyawa ini termasuk dalam kelompok triterpenoid (Vinoth, 2012).

Biji mimba juga mengandung beberapa komponen aktif pestisida antara lain azadirachtin, salannin, azadiradion, salannol, salanolacetate, 3- deacetyl salannin, 14-epoxyazadiradion, gedunin, nimbenin, dan deacetyl nimbinen. Senyawa azadirachtin berfungsi sebagai penolak makan, toksikan, dan pengganggu pertumbuhan terhadap berbagai jenis hama dan relatif aman terhadap manusia dan binatang (Thomson, 1992). Azadirakthin dapat menimbulkan berbagai pengaruh pada serangga, seperti hambatan aktivitas makan, ketahanan hidup, gangguan perkembangan dan lain sebagainya (Sari dan Suharsono, 2014).

Pestisida dari biji nimba dapat diproduksi baik dengan teknologi yang sederhana maupun teknologi tinggi. Produksi teknologi sederhana adalah dengan cara menggiling atau menumbuk biji nimba menjadi serbuk, kemudian direndam dalam air selama 24 jam, disaring kemudian dapat diaplikasikan (Nurindah et al, 2004).

Minyak dan lemak merupakan senyawa lipida yang paling banyak di alam. Perbedaan antara keduanya terletak pada sifat fisik atau konsistensi pada suhu kamar. Lemak berbentuk padat pada suhu kamar sedangkan minyak berbentuk cair.Perbedaan ini terjadi karena perbedaan jumlah ikatan rangkap, panjang rantai dan bentuk isomer Cis atau Trans pada asam lemak tidak jenuh (Kataren, 1996).

Minyak kelapa diperoleh dari daging buah kelapa. Minyak kelapa akan mengalami perubahan komposisi kimia dengan bertambahnya umur buah. Hasil analisis asam lemak yang paling dominan pada minyak kelapa yaitu asam laurat (C12:0) sebesar $48,24 \%$, diikuti oleh asam lemak miristat (C14) sebesar 19,26\% 
(Karouw et al, 2013). pH dari minyak kelapa murni umumnya yaitu sekitar 5.

Minyak kemiri mengandung asam lemak jenuh dan tak jenuh. Asam lemak jenuh yang terkandung dalam minyak kemiri yaitu asam palmitat $(4,38 \%)$ dan asam stearat $(3,93 \%)$. Sedangkan asam lemak tak jenuh seperti asam oleat $(26,23 \%)$, asam linoleat (39,62\%), asam linolenat $(20.76 \%)$, dan asam arachidat $(0,08 \%)$ (Paimin, 1994).

Komposisi asam lemak didalam minyak kemiri berbeda-beda, hal ini disebabkan oleh perbedaan tempat tumbuh maupun metode analisisnya.

Minyak zaitun diperoleh dari proses ekstraksi buah zaitun yang telah matang. Minyak zaitun selain dikenal sebagai penambah cita rasa masakan, minyak ini juga memiliki beragam manfaat bagi kesehatan maupun kecantikan. Minyak zaitun kerap dianggap sebagai minyak yang sehat karena mengandung lemak tak jenuh yang tinggi (utamanya asam oleic dan polifenol (Fahri et al, 1996). Asam Oleat didalam minyak zaitun 55-83\% dari total asam lemak. Kandungan minyak zaitun yaitu alkaloid, saponin dan tannin. Dalam beberapa penelitan menemukan adanya flafonoid, apigenin, luteolin, chryseriol dan turunanya (Fahri et al, 1996). Komponen penting didalam minyak zaitun yaitu senyawa tokoferol (vitamin E), yang terdiri dari tokoferol alfa, beta gama dan delta. Jenis alfa konsentrasinya hamper mencapai $90 \%$ dari total tookferol. Sehingga miyak ini sangat ideal sebagai antioksidan (Kinanti, 2009).

Tujuan dari penelitian ini yaitu mengetahui hasil dari organoleptik serbuk biji nimba (Azadirachta indica) dalam variasi minyak.

\section{METODE PENELITIAN}

Penelitian ini dilaksanakan di Laboratorium Kimia Dasar, Program Studi Farmasi, Fakultas Ilmu Kesehatan, Universitas Ibrahimy Sukorejo Situbondo.

Alat yang digunakan dalam penelitian ini adalah corong kaca, gelas beaker, batang pengaduk, alumunium foil, kertas saring, plastik warp, neraca analitik, timba, kompor listrik, cawan alumunium, kaca arloji, cup plastik, nampan, kain saring, saringan atau sieve ayakan, toples, pipet tetes, botol sampel, termometer, cawan alumunium. kertas lakmus atau $\mathrm{pH}$ universal. Bahan yang digunakan 
dalam penelitian ini adalah biji nimba (Azadirachta indica), akuades, minyak kemiri, minyak kelapa dan minyak zaitun.

Metode yang digunakan dalam penelitian ini adalah metode maserasi kemudian diikuti dengan metode infus minyak. Metode maserasi merupakan metode ekstraksi dingin, yakni tidak melibatkan pemanasan. Proses Maserasi dilakukan dengan cara merendam simplisia didalam minyak selama 24 jam. Metode infus minyak merupakan metode yang hampir sama dengan proses difusi dan osmosis, namun pada penelitian ini menggunakan minyak sebagai pelarut pembawaa. Minyak yang digunakan dalam penelitian ini yaitu minyak kelapa, minyak kemiri dan minyak zaitun.

Tahapan penelitian dimulai dari persiapan dan pembuatan simplisia, proses maserasi, infus minyak, analisis data. Analisis data pada penelitian ini bersifat deskriptif kualitatif dan studi literatur. Penelitian ini menggunakan Uji Organoleptik berupa pengamatan warna (jernih atau tidak jernih), aroma (tengik atau tidak tengik) dan pengukuran $\mathrm{pH}$ serbuk biji nimba dalam variasi minyak.
Prosedur pertama yaitu pengumpulan biji nimba (Azadirachta indica) dilakukan secara manual dan secara acak yakni diambil buah yang muda (berwaran hijau) hingga yang tua (berwarna kuning). Pengumpulan dilakukan di sekitar Kabupaten Situbondo. Kemudian biji dicuci dengan air mengalir dan dikering anginkan atau dijemur dibawah sinar matahari selama 3 hari, tujuan ini untuk mengurangi kadar air yang terkandung dalam biji nimba. Biji nimba yang telah kering dihaluskan dengan menggunkan mesin giling hingga diperoleh serbuk halus biji nimba, kemudian serbuk ini diayak dengan ayakan 40 mesh.

Tahapan ekstrasi maserasi massa biji nimba yang digunakan yaitu 50 gram dan volume minyak masingmasing sebesar $150 \mathrm{~mL}$. Pada proses maserasi ini, serbuk biji nimba dan minyak dicampur didalam cup plastik dengan perbandingan antara serbuk dan minyak pembawa 1:3, dilakukan pengadukan kemudian cup plastik ditutup dengan plastic warp, dilapisi alumunium foil serta tutup plastik.

Pada tahap ini juga disiapkan kontrol dari masing-masing sampel yaitu minyak tanpa serbu biji nimba. Biji nimba dalam direndam dalam 
minyak kelapa, minyak kemiri dan minyak zaitun selama 24 jam dan dihindarkan dari sinar matahari langsung. Proses ini dilakukan pengulangan sebanyak 2 kali. Hasil rendaman masing-masing diaduk kemudian dilakukan proses ekstraksi infus minyak.

Tahapan ekstraksi infus minyak biji nimba (Azadirachta indica) dalam masing-masing minyak diaduk dan dipanaskan pada suhu $90^{\circ} \mathrm{C}$ selama 15 menit disertai pengadukan yang teratur. Setelah selesai, sampel diangkat dan didinginkan pada suhu ruang kemudian disaring menggunakan corong kaca, kain saring dan kertas saring. Filtrat yang diperoleh dimasukkan kedalam botol dan diberi label, kemudian dilakukan Uji Organoleptik. Pada uji organoleptik filtrat masing-masing diamati aroma, $\mathrm{pH}$ dan warnanya. Parameter pengamatan warna jernih atau tidak jernih, untuk aroma ketengikan dari minyak (tengik atau tidak tengik) dan pengukuran $\mathrm{pH}$ masing-masing sampel menggunakan kertas lakmus atau $\mathrm{pH}$ universal.

\section{HASIL DAN PEMBAHASAN}

Penelitian ini dilakukan dengan metode ekstraksi maserasi biji niimba dalam variasai minyak. Hasil perendaman berupa ekstrak kental pekat, kemudian diaduk dan dilakukan metode infus minyak dengan pemanasan $90^{\circ} \mathrm{C}$. Proses pemanasan berfungsi untuk mengoptimalkan proses difusi atau penyerapan senyawasenyawa yang ada pada biji nimba dalam minyak.

Pada Gambar 1 menunjukkan hasil serbuk biji nimba dalam variasi minyak setelah proses penyaringan kemudian dilakukan proses uji organoleptik. Uji Organoleptik bertujuan untuk mengetahui perubahan fisik dan kimia yang terjadi pada sampel setelah perlakuan.

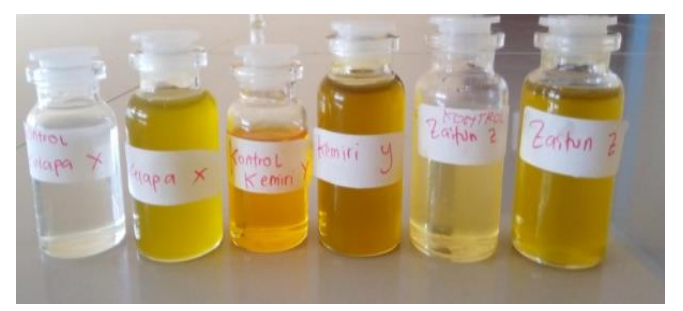

Gambar 1. Serbuk Biji Nimba dalam Variasi Minyak setelah Proses Penyaringan

Berdasarkan pengamatan yang dilakukan, terjadi perubahan fisik pada ketiga minyak, yang terlihat jelas pada warna masing-masing minyak. Ketiga sampel dibandingkan dengan kontrol 
masing-masing minyak. Perbedaan warna dari ketiganya sangat jelas (gambar 1). Warna dari sampel serbuk biji nimba dalam minyak kelapa menunjukkan warna tidak jernih, hal ini terjadi karena adanya senyawasenyawa pada biji nimba (Azadirachta indica) yang terikat atau bereaksi dengan minyak kelapa. Hasil pengamatan warna pada minyak kemiri dan zaitun juga menunjukkan hasil yang sama, yaitu warna yang dihasilkan tidak jernih (Tabel 1).

Tabel 1. Hasil Pengamatan Uji Organoleptik Warna.

\begin{tabular}{|c|c|c|}
\hline \multirow[b]{2}{*}{ Minyak } & \multicolumn{2}{|c|}{$\begin{array}{c}\text { Uji Organoleptik } \\
\text { Warna }\end{array}$} \\
\hline & Jernih & Tidak Jernih \\
\hline A1 & - & $\sqrt{ }$ \\
\hline $\mathrm{A} 2$ & - & $\sqrt{ }$ \\
\hline$X$ & - & $\sqrt{ }$ \\
\hline B1 & - & $\sqrt{ }$ \\
\hline B2 & - & $\sqrt{ }$ \\
\hline $\mathrm{Y}$ & - & $\sqrt{ }$ \\
\hline $\mathrm{C} 1$ & - & $\sqrt{ }$ \\
\hline $\mathrm{C} 2$ & - & $\sqrt{ }$ \\
\hline Z & - & $\sqrt{ }$ \\
\hline
\end{tabular}

Keterangan:

$A=$ Serbuk Biji Nimbah + Minyak Kelapa

$\mathrm{B}=$ Serbuk Biji Nimbah + Minyak

Kemiri

$\mathrm{C}=$ Serbuk Biji Nimbah + Minyak

Zaitun

$\mathrm{X}=$ Kontrol Minyak Kelapa

$\mathrm{Y}=$ Kontrol Minyak Kemiri

$\mathrm{Z}=$ Kontrol Minyak Zaitun
Kandungan biji nimba didominasi oleh senyawa azadirachtin yang termasuk golongan senyawa terpenoid. Terpenoid merupakan senyawa yang bersifat non polar maka proses ekstraksinya dapat menggunakan pelarut non polar (Kristanti dkk, 2008). Dalam penelitian ini minyak pembawa (minyak kelapa, minyak kemiri dan minyak zaitun) bersifat non polar sehingga pada saat ekstraksi (maserasi dan infus minyak) diindikasikan terdapat senyawasenyawa pada biji nimba yang bereaksi dan terikat dalam minyak yang ditandai dengan perubahan warna pada masingmasing minyak.

Uji organoleptik yang selanjutnya yaitu dilakukan pengukuran nilai $\mathrm{pH}$ dari masingmasing minyak. $\mathrm{pH}$ awal minyak sebelum perlakuan adalah $\mathrm{pH}$, yang menunjukkan bahwa ketiga sampel bersifat asam hal ini sesuai dengan kandungan minyak yang tersusun atas asam lemak, baik asam lemak jenuh maupun tak jenuh.

Proses perendaman dan pemanasan serbuk biji nimba pada masing-masing minyak berpengaruh pada nilai $\mathrm{pH}$. Hal ini dibuktikan dengan membandingkan nilai $\mathrm{pH}$ 
minyak sebelum perlakuan dan setelah perlakuan. Hasil pengukuran $\mathrm{pH}$ dari masing-masing sampel menunjukkan angka yang sama yaitu 6 (Tabel 2). Nilai $\mathrm{pH}$ minyak mengalami perubabahan dari 5 menjadi 6 setelah perlakuan.

Uji organoleptik yang terakhir yaitu pengamatan aroma dari masingmasing minyak. Parameter pengamatan dilihat ketengikan pada masing-masing minyak. Tingkat ketengikan minyak tergantung dari kadar air yang terkandung dalam sampel.

Tabel 2. Hasil Pengamatan Uji Organoleptik Aroma dan $\mathrm{pH}$.

\begin{tabular}{|c|c|c|c|}
\hline \multirow{3}{*}{ Minyak } & \multicolumn{3}{|c|}{ Uji Organoleptik } \\
\hline & & Aroma & \\
\hline & Tengik & Tidak Tengik & pH \\
\hline $\mathrm{A} 1$ & - & $\sqrt{ }$ & 6 \\
\hline A2 & - & $\sqrt{ }$ & 6 \\
\hline $\mathrm{X}$ & - & $\sqrt{ }$ & 6 \\
\hline B1 & - & $\sqrt{ }$ & 6 \\
\hline B2 & - & $\sqrt{ }$ & 6 \\
\hline Y & - & $\sqrt{ }$ & 6 \\
\hline $\mathrm{C} 1$ & - & $\sqrt{ }$ & 6 \\
\hline $\mathrm{C} 2$ & - & $\sqrt{ }$ & 6 \\
\hline $\mathrm{Z}$ & - & $\sqrt{ }$ & 6 \\
\hline
\end{tabular}

Hasil dari pengamatan minyak kelapa menunjukkan bahwa minyak kelapa tidak tengik. Hasil pengamatan pada minyak kemiri dan minyak zaitun juga menunjukkan hasil yang sama yaitu keduanya tidak tengik (Tabel 2). Hasil pengamatan ini menunjukkan bahwa kadar air masing-masing sampel sangat rendah.

\section{SIMPULAN DAN SARAN}

Berdasarkan penelitian yang telah dilakukan dapat tarik kesimpulan bahwa hasil uji organoleptik warna pada ketiga minyak (minyak kelapa, minyak kemiri dan minyak zaitun) menunjukkan bahawa minyak tidak jernih, pengukuran $\mathrm{pH}$ pada masingmasing minyak terjadi kenaikan $\mathrm{pH}$ dari 5 menjadi 6. Pengamatan Aroma dari masing-masing minyak menunjukkan bahwa minyak kelapa tidak tengik, begitu pula untuk minyak kemiri dan zaitun. Saran dalam penelitian ini yaitu perlu dilakukan uji lanjutan untuk mengetahui senyawa apasaja didalam biji nimba (Azadirachta indica) yang terikat dan bereaksi pada minyak pembawa. 


\section{DAFTAR PUSTAKA}

Fahri, B., Aiche, J. M., Mard, S., Korbi, S., dan Lamaison, J. L. 1996. Olea europea L: Stimulant, anti-ulcer, antiinflamatory effects. Chim Pharm. 135(1):42-49.

Karouw, S., Suparmo, Hatuti, P., dan Utami, T. 2013. Sintesis Ester Metil Rantai Medium dari Minyak Kelapa dengan Cara Metanolisis Kimiawi.Agritech. 33(2):182-188.

Kataren, S. 1996. Pengantar Teknologi Minyak dan Lemak Pangan. Jakarta: Universitas Indonesia.

Kinanti. 2009. Minyak Zaitun (Sumber Lemak Nabati). [serial online] http://kinanthidiah.multiply.co m/journal/item/4/.(20 Maret 2019).

Nurindah, Parmono DH, Sujak. 2006. Faktor mortalitas biotic Helicoverpa armigera (Hubner) pada kapas tumpangsari dengan kedelai. Prosiding Lokakarya Revitalisasi Agribisnis Kapas Diintegrasikan dengan Palawija di Lahan Sawah Tadah Hujan, Lamongan 8 September 2005, p:110 - 117.

Sari, K.P dan Suharsono. 2014. Efikasi: insektisida nabati dalam mengendalikan kutu kebul, (Bemisia tabaci Genn). (Homoptera: Aleyrodidae). Widyariset. 17 (2): 219-266.

Schmutterer, H. 1990. Properties and Potential of Natural Pesticides from Neem Tree, Azadirachta indica. Ann. Rev. Entomol. 35 : $271-295$.

Paimin, F. R. 1994. Kemiri, Budidaya dan Prospek Bisnis. Jakarta: Penebar Swadaya.

Thomson, W.T. 1992. Agricultural Chemicals. Book I: Insecticides. Fresno, CA: Thomson Publications.

Vinoth, B. dkk. 2012. Phytochemical analysis and antibacterial activity of azadirachta indica a juss. International journal of research in plant science.2(3) 2012.

Winarno, F.G. 2003.OMEGA-9 Perannya dalam Diet Jantung Sehat.[Serial online].http://www.intiboga.co m/omega9b.htm. (20-Februari2019). 
